\title{
Antimicrobial drug resistance and its significance in Medlife Genesys Clinic in Arad
}

\author{
Dana Negru*, Angela Cionca², Laura Nicolescu', Raluca lanota ${ }^{2}$ \\ From The 9th Edition of the Scientific Days of the National Institute for Infectious Diseases Prof Dr Matei Bals \\ Bucharest, Romania. 23-25 October 2013
}

\section{Background}

Antimicrobial drugs have played a decisive role in decreasing illness and death associated with infectious diseases but selective pressure exerted by antimicrobial drug use also has been the major driving force behind the emergence and spread of drug-resistance traits among pathogenic and commensal bacteria.

\section{Methods}

We conducted a retrospective study on isolates recovered from hospital and ambulatory care settings samples during 2012 to assess antimicrobial drug resistance. Our study has limitations resulted in an incomplete or absent patient information regarding prior treatment history, and potential for bias in selecting isolates that were ultimately tested in this study. Isolate sets cannot be considered truly random; we had no data for prior antimicrobial drug exposure, travel, and other epidemiologic information.

\section{Results}

A total of 157 isolates were tested for pathogenity and 124 for susceptibility to 24 antimicrobial drugs. A significant multidrug resistance ( $\geq 3$ antimicrobial drug classes) was observed for 47 isolates, including Staphylococcus aureus, Escherichia coli and Pseudomonas aeruginosa $(\mathrm{p}<0.001)$, in relation with the origin of samples and patients ages, regardless of medical settings. Methicillinresistant Staphylococcus aureus (MRSA) represented only $17.5 \%$ of the Staphylococcus aureus specimens. In $10 \%$ of cases $E$ coli isolates were resistant to fluoroquinolones. Only 15\% of Pseudomonas aeruginosa isolates were resistant to aminoglycosides, carbapenems and ceftazidime. Surgical wounds were significantly involved in detected resistance to antimicrobial isolates, mainly in young

\footnotetext{
* Correspondence: negrudana30@yahoo.com

${ }^{1}$ Public Health Department, Arad, Romania

Full list of author information is available at the end of the article
}

patients, aged 25-34 $(\mathrm{p}<0.0001)$. There is no significant difference regarding hospital and ambulatory care settings.

\section{Conclusion}

Our study showed that antimicrobial drug resistance ranged from $9.52 \%$ to $50 \%$, with $17.5 \%$ MRSA. Fluoroquinolone-resistant $E$ coli in community urinary tract infections has the same patterns by either primary or tertiary caregivers.

\section{Authors' details}

${ }^{1}$ Public Health Department, Arad, Romania. ${ }^{2}$ MedLife Genesys Clinic, Arad, Romania.

Published: 16 December 2013

doi:10.1186/1471-2334-13-S1-P31

Cite this article as: Negru et al:: Antimicrobial drug resistance and its significance in Medlife Genesys Clinic in Arad. BMC Infectious Diseases 2013 13(Suppl 1):P31.

Submit your next manuscript to BioMed Central and take full advantage of:

- Convenient online submission

- Thorough peer review

- No space constraints or color figure charges

- Immediate publication on acceptance

- Inclusion in PubMed, CAS, Scopus and Google Scholar

- Research which is freely available for redistribution

Submit your manuscript at www.biomedcentral.com/submit
() Biomed Central

\section{() Biomed Central}

C 2013 Negru et al; licensee BioMed Central Ltd. This is an Open Access article distributed under the terms of the Creative Commons Attribution License (http://creativecommons.org/licenses/by/2.0), which permits unrestricted use, distribution, and reproduction in any medium, provided the original work is properly cited. 